Proc. Passivity and Breakdown Session, 1997 Joint Intern. Meeting of the Electrochemistry Soc. and Intern. Soc. of

\title{
INFLUENCE OF SOLUTION CHEMISTRY ON DISSOLUTION OF ARTIFICIAL PASSIVE FILMS
}

\author{
S. Virtanen, P. Schmuki, H.S. Isaacs ${ }^{1}$, M.P. Ryan ${ }^{1}$, L.J. Oblonsky ${ }^{1}$, M. Vippola ${ }^{2}$, and \\ H. Böhni \\ Swiss Federal Institute of Technology, Institute of Materials Chemistry and Corrosion, \\ ETH-Hönggerberg, 8093 Zurich, Switzerland \\ 1Brookhaven National Laboratory, Materials Science Division, Department of Applied \\ Science, Upton, NY 11973 \\ ${ }^{2}$ Tampere University of Technology, Institute of Material Science, P.O. Box 589, 33101
} Tampere, Finland

\begin{abstract}
The dissolution behavior of artificial $\mathrm{Fe}, \mathrm{Cr}$, and $\mathrm{Fe} / \mathrm{Cr}$ passive films
(sputter-deposited $\mathrm{Fe} / \mathrm{Cr}$ oxide films on inert substrates) was studied by EEIVED in situ X-ray absorption near edge spectioscopy (XANES). Low $\mathrm{pH}$ and presence of halides ( $\mathrm{Cl}^{-}$and $\mathrm{F}^{-}$) accelerate the dissolution due to the solubility of $\mathrm{Fe}$ oxides in these solutions. The presence of $\mathrm{Fe}(2+)$ in the oxide film strongly accelerates dissolution in acidic solution. For mixed $\mathrm{Fe} / \mathrm{Cr}$ oxides, $\mathrm{F}-$ leads to a selective dissolution of $\mathrm{Fe}$ oxide. $\mathrm{Cr}_{2} \mathrm{O}_{3}$ is not attacked by fluoride; hence if mixed oxide films contain a sufficient amount of $\mathrm{Cr}$ oxide, dissolution stop is obtained, probably by surface enrichment of $\mathrm{Cr}$ oxide. The composition of the oxide film is also crucial for its electrochemical stability. An increasing $\mathrm{Cr}_{2} \mathrm{O}_{3}$ content increases the resistance against reductive dissolution, increases the resistance in aggressive solutions (low $\mathrm{pH}$, halides), but decreases the resistance against oxidative dissolution.

\section{INTRODUCTION}

One key factor determining the stability of the passive state is the chemical and/or electrochemical dissolution behavior of passive films. However, most experimental approaches probe the behavior of an alloy/film system and hence it is difficult to obtain direct information on the properties of the passive film itself. This is the case especially in the presence of aggressive species in the solution, which can lead to pitting and thus to an attack of the underlying alloy. Therefore, in the present work, the dissolution behavior of oxide films was studied using thin, sputter-deposited oxide films ("artificial passive films") on an inert substrate (Ta). This approach is similar to earlier work by Sugimoto et al. $(1,2)$ , who studied in acidic solutions the dissolution of thin $\mathrm{Fe}_{2} \mathrm{O}_{3}-\mathrm{Cr}_{2} \mathrm{O}_{3}$ films prepared by metalorganic chemical vapor deposition. In previous work we investigated the effect of the $\mathrm{Cr}_{2} \mathrm{O}_{3}$ content of mixed $\mathrm{Fe}-\mathrm{Cr}$ oxide films on the electrochemical behavior (3), in continuation of previous work on thin iron- $(4,5)$ and chromium-oxide layers (6). In these investigations, in situ $X$-ray absorption near edge spectroscopy (XANES) measurements were carried out during the electrochemical experiments to monitor dissolution and changes in the valence state as a function of potential and solution chemistry. It was found that the electrochemical dissolution behavior strongly depends on

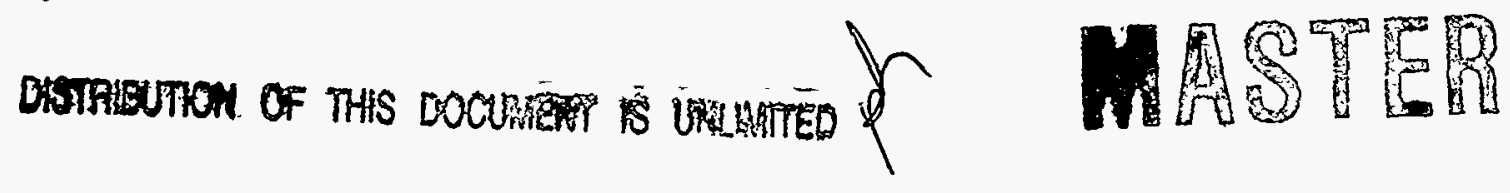


the oxide composition. At low $\mathrm{Cr}$ oxide concentrations and with pure $\mathrm{Fe}$ oxide, the films dissolve when cathodically polarized, and are resistant to dissolution, when polarized in the anodic direction. At high $\mathrm{Cr}_{2} \mathrm{O}_{3}$ concentrations and with pure $\mathrm{Cr}$ oxide, dissolution occurs when the films are anodically polarized, but the films are stable against cathodic dissolution. In the intermediate $\mathrm{Cr}$ oxide concentration range, the oxides neither dissolve under anodic nor cathodic polarization. Hence, a critical composition range exists for the dissolution resistance of the oxide. An acidic environment was found to accelerate both anodic and cathodic dissolution, associated with chemical dissolution of the iron oxide. In the present work, the effect of solution chemistry on the dissolution behavior of such artificial passive films is studied in more detail.

\section{EXPERIMENTAL}

The oxide films were prepared by r.f. sputter deposition using oxide targets $\left(\mathrm{Fe}_{2} \mathrm{O}_{3}\right.$, $\mathrm{Cr}_{2} \mathrm{O}_{3}, \mathrm{Fe}_{2-\mathrm{x}} \mathrm{Cr}_{\mathrm{x}} \mathrm{O}_{3}$ with $\left.[\mathrm{Cr}]=10,20,50,90 \%\right)$. The r.f. sputtering system has been previously described elsewhere (7). Before each deposition, the sputter chamber was evacuated to a pressure of 4 to $7 \times 10^{-4} \mathrm{~Pa}$. The deposition was carried out in pure $\mathrm{Ar}$ (99.998\%). The oxide films were characterized by scanning electron microscopy (SEM), $\mathrm{X}$-ray diffraction (XRD), and analytical transmission electron microscopy (TEM). The composition of the oxide film is near to that of the targets, with a slightly reduced $\mathrm{Cr}$ content. All mixed oxides, as well as pure $\mathrm{Cr}_{2} \mathrm{O}_{3}$ show an amorphous structure, whereas $\mathrm{Fe}_{2} \mathrm{O}_{3}$ is deposited in a crystalline structure $\left(\alpha-\mathrm{Fe}_{2} \mathrm{O}_{3}\right)$. Details of the characterization of the samples are given elsewhere $(8,9)$.

The oxide films were sputter-deposited onto Mylar (6 $\mu \mathrm{m})$, which had been previously coated by sputter-depositing a thin layer of tantalum $(20$ to $30 \mathrm{~nm})$ to establish a back contact to the samples. The electrochemical cell has been described previously $(10,11)$. XANES measurements were carried out in situ during the electrochemical treatment of the samples. The electrolyte solutions were continuously deaerated with a stream of $\mathrm{Ar}$ bubbles. The potentials were measured and are reported against a saturated mercury sulfate reference electrode (MSE, $\approx+0.4 \mathrm{~V}(\mathrm{SCE})$ ). A platinum wire was used as a counter electrode. The solutions were prepared from reagent grade chemicals and distilled water (Millipore Q, $18 \mathrm{M} \Omega$ ).

XANES measurements were carried out at Beamlines X10C and X19A at the National Synchrotron Light Source at Brookhaven National Laboratory. The energy scale was calibrated by taking the peak in the first derivative of a spectrum from an iron foil to be the position of the $\mathrm{Fe} \mathrm{K}$ edge at $7112 \mathrm{eV}$ and for chromium foil the $\mathrm{Cr} \mathrm{K}$ edge at $5989 \mathrm{eV}$. The monochromator energy was periodically checked and was found to be very stable during the measurements. Spectra at the $\mathrm{Cr}$ and $\mathrm{Fe} \mathrm{K}$ edges were collected sequentially. Data was collected with a 0.2-0.5 eV step size in the region near to the edge. The edge position was defined as the energy value at the half-height of the peak after background subtraction. The edge height was determined at an energy $100 \mathrm{eV}$ above the edge after the background was subtracted out of each spectrum by extrapolating the curve fitted to the signal below the edge. In situ measurements on the electrochemically controlled samples were made using 


\section{DISCLAIMER}

This report was prepared as an account of work sponsored by an agency of the United States Government. Neither the United States Government nor any agency thereof, nor any of their employees, make any warranty, express or implied, or assumes any legal liability or responsibility for the accuracy, completeness, or usefulness of any information, apparatus, product, or process disclosed, or represents that its use would not infringe privately owned rights. Reference herein to any specific commercial product, process, or service by trade name, trademark, manufacturer, or otherwise does not necessarily constitute or imply its endorsement, recommendation, or favoring by the United States Government or any agency thereof. The views and opinions of authors expressed herein do not necessarily state or reflect those of the United States Government or any agency thereof. 


\section{DISCLAMMIER}

Portions of this document may be illegible in electronic image products. Images are produced from the best available original document. 
fluorescence detection set up with a Canberra 13-element solid-state detector. Further details of the geometry are given in reference (10) .

\section{RESULTS AND DISCUSSION}

\section{Effect of solution $\mathrm{pH}$}

Figure 1 shows an example of the dissolution behavior of a thin $\mathrm{Fe}_{2} \mathrm{O}_{3}$ film during galvanostatic reduction in different solutions; shown is the thickness of the sample determined from the edge height of the XANES spectra as a function of charge density. Clearly, dissolution is accelerated in the acidic solution, whereas in the alkaline solution no change in the thickness takes place. A detailed study of the spectral changes (edge position) during the experiment revealed that the accelerated dissolution in the acidic solution is due to a chemical dissolution of the reduced iron oxide in addition to electrochemical dissolution, whereas in the alkaline solution a solid-state conversion into a ferrous hydroxide/oxide with no dissolution takes place. At potentials anodic to the reduction region $\left(\mathrm{Fe}^{3+-}>\mathrm{Fe}^{2+}\right), \mathrm{Fe}_{2} \mathrm{O}_{3}$ and $\mathrm{Fe}_{3} \mathrm{O}_{4}$ thin films dissolve chemically in strong $\mathrm{HCl}$ and $\mathrm{H}_{2} \mathrm{SO}_{4}(5)$. The chemical dissolution rate is strongly $\mathrm{pH}$-dependent: the higher the acid concentration, the faster the dissolution.

For pure $\mathrm{Cr}$ oxide films, dissolution was never found under cathodic polarization, independent of the electrolyte composition. On the other hand, under anodic polarization oxidative dissolution $\left(\mathrm{Cr}^{3+}-->\mathrm{Cr}^{6+}\right)$ takes place. As illustrated in Fig. 2, the kinetics of oxidative dissolution of pure $\mathrm{Cr}$ oxides was found to be independent of $\mathrm{pH}$. In all solutions studied, the oxidation reaction took place with a $100 \%$ current efficiency.

In the case of mixed oxides, the dissolution behavior strongly depends on the composition of the oxide film. Oxides with a high $\mathrm{Cr}$ oxide content are generally prone to oxidative dissolution, whereas oxides with a high $\mathrm{Fe}$ oxide content dissolve under cathodic polarization. A comparison with the pure iron and chromium oxides shows that even the addition of small amounts (10\%) of the non-dissolving species retards dissolution. In borate buffer ( $\mathrm{pH} 8.4$ ), the mixed oxide films do not suffer from reductive or oxidative dissolution in a wide composition range. This is illustrated in Fig. 3 showing the dissolution rates for $\mathrm{Fe} / \mathrm{Cr}$ oxide films as a function of the $\mathrm{Cr}_{2} \mathrm{O}_{3}$ content of the film during galvanostatic oxidation and reduction $\left(+/-10 \mu \mathrm{A} / \mathrm{cm}^{2}\right)$ in borate buffer. The dissolution rates were determined from the drop of the edge height of the XANES spectra during the experiment.

Figure 4 shows the effect of solution composition (borate buffer / $0.1 \mathrm{MH}_{2} \mathrm{SO}_{4}$ ) on the dissolution rates of mixed $\mathrm{Fe} / \mathrm{Cr}$ oxides as a function of the $\mathrm{Cr}$ oxide content during galvanostatic reduction (4a) and oxidation (4b). The composition range of high stability is strongly diminished in the acidic solution $\left(0.1 \mathrm{M} \mathrm{H}_{2} \mathrm{SO}_{4}\right)$. This can be attributed to chemical dissolution of iron oxide.

Looking at the XANES spectra in detail during reduction reveals more information on the dissolution mechanism. Figure 5 shows the $\mathrm{Fe}$ edge with an expanded energy scale near to the edge region for a $10 \% \mathrm{Cr}_{2} \mathrm{O}_{3}-90 \% \mathrm{Fe}_{2} \mathrm{O}_{3}$ sample during galvanostatic 
reduction in borate buffer (5a) and in $0.1 \mathrm{M} \mathrm{H}_{2} \mathrm{SO}_{4}(5 \mathrm{~b})$. In order to compare the edge position for the dissolving sample, the spectra were normalized to unity edge height after background substraction. Clearly, in the case of reduction in borate buffer, dissolution is accompanied with a shift of the edge position into the negative direction indicating a decrease of the average valency of the Fe oxide. However, during reduction in the acidic solution, almost no edge shift is found. Hence, the acceleration of dissolution in the acidic solution is due to the chemical dissolution of the reduced $\mathrm{Fe}(2+)$ species. This behavior is very similar to the behavior of pure $\mathrm{Fe}_{2} \mathrm{O}_{3}$ films. In the case of higher $\mathrm{Cr}_{2} \mathrm{O}_{3}$-containing oxide films, where no dissolution takes place during reduction in the acidic solution, an identical edge shift is found in borate buffer and in $0.1 \mathrm{M} \mathrm{H}_{2} \mathrm{SO}_{4}$

The role of $\mathrm{Fe}(2+)$ in the oxide film in decreasing its stability has been already shown for pure iron oxide films, comparing the dissolution behavior of sputter-deposited films of $\mathrm{Fe}_{3} \mathrm{O}_{4}$ and $\mathrm{Fe}_{2} \mathrm{O}_{3}(5)$. In the case of mixed $\mathrm{Fe} / \mathrm{Cr}$ oxide films, it is possible to convert the $\mathrm{Fe}$ species of the film into a lower valent state, since depending on the $\mathrm{Fe} / \mathrm{Cr}$ ratio dissolution of the $\mathrm{Fe}(2+)$ species does not take place. Hence, the dissolution characteristics of mixed $\mathrm{Fe} / \mathrm{Cr}$ oxide films with a varying amount of $\mathrm{Fe}(2+)$ in the oxide can be investigated. The XANES data enables a simultaneous monitoring of dissolution and average valency. An example of such a measurement is shown in Figs. 6,7. In Fig. 6 the XANES spectra are shown for a $20 \% \mathrm{Cr}_{2} \mathrm{O}_{3}-80 \% \mathrm{Fe}_{2} \mathrm{O}_{3}$ sample during anodic potential steps in $0.1 \mathrm{M} \mathrm{H}_{2} \mathrm{SO}_{4}$. Polarization form the open-circuit potential up to $+600 \mathrm{mV}$ does not lead to any dissolution. However, at higher anodic potentials dissolution of $\mathrm{Fe}$ is observed. The Cr edge XANES spectra show that at these potentials oxidative dissolution of $\mathrm{Cr}$ oxide takes place, and this results in a co-loss of the otherwise insoluble Fe oxide species. However, if the Fe oxide species in the oxide film is first converted into $\mathrm{Fe}(2+)$ as seen from the edge shift during reduction in borate buffer (Fig. 7 ), then a subsequent exposure to $0.1 \mathrm{M} \mathrm{H}_{2} \mathrm{SO}_{4}$ at potentials lower than the $\mathrm{Cr}$ oxidative dissolution range leads to a fast dissolution of the Fe oxide.

Figure 8 shows a summary of a similar experiment on a $50 \% \mathrm{Cr}_{2} \mathrm{O}_{3}-50 \% \mathrm{Fe}_{2} \mathrm{O}_{3}$ sample. This sample was again first reduced in borate buffer leading to a conversion of $\mathrm{Fe}(3+)$ to $\mathrm{Fe}(2+)$ without dissolution, and then exposed to $0.1 \mathrm{M} \mathrm{H}_{2} \mathrm{SO}_{4}$. Subsequently, the potential was anodically stepped in $100 \mathrm{mV}$ steps. In Figure 8 , the edge height and edge position are shown as a function of potential during the anodic steps in $\mathrm{H}_{2} \mathrm{SO}_{4}$. Clearly, dissolution of Fe takes place as long as the edge position indicates the presence of $\mathrm{Fe}(2+)$ in the oxide. After all of the $\mathrm{Fe}$ has been oxidized to $\mathrm{Fe}(3+)$, no further dissolution takes place. Hence, not only the $\mathrm{Fe} / \mathrm{Cr}$ ratio in the oxide but the valency of the iron oxide as well has a major influence on the stability of the oxide film.

\section{Effect of agoressive anions}

Since halide anions lead to localized breakdown of passivity, it is of an interest to study their effect on the dissolution behavior of the oxide film. An XPS study by Khalil, Haupt and Strehblow on the effect of halide ions on the passive film on Fe has shown that a pronounced thinning of the passive film occurs in solutions containing $\mathrm{Cl}^{-}, \mathrm{Br}$, and $\mathrm{I}^{-}(12)$ - Support for the dissolution of the passive film on iron in the presence of $\mathrm{Cl}^{-}$in the solution was also given by a rotating ring-disc study by Heusler and Fischer (13). In the present work, the influence of $\mathrm{Cl}^{-}$and $\mathrm{F}^{-}$in the electrolyte on the dissolution behavior of 
artificial passive films was studied. It is of a special interest to compare the effect of these halide anions, since it is well-known that a general attack of Fe takes place in fluoride solutions, whereas chloride leads to localized breakdown of iron passivity (14-16) .

Figure 9 shows a comparison of the Fe edge XANES spectra during galvanostatic reduction of $10 \% \mathrm{Cr}_{2} \mathrm{O}_{3}-90 \% \mathrm{Fe}_{2} \mathrm{O}_{3}$ oxide film in borate buffer containing either $1 \mathrm{M}$ $\mathrm{NaCl}(9 \mathrm{a})$ or $1 \mathrm{M} \mathrm{NaF}(9 \mathrm{~b})$. A strikingly faster dissolution takes place in the presence of fluorides in the solution. The remarkably higher dissolution rate of the oxide films in presence of fluoride as compared to chloride may be due to the significantly higher tendency for complex formation of $\mathrm{Fe}(3+)$ by $\mathrm{F}^{-}$than by $\mathrm{Cl}^{-}(17)$.

In Fig. 10, the spectra of Fig. 9 are shown normalized and with an expanded energy scale near to the edge. Clearly, in both cases an edge shift towards more negative energies is found during the reduction. In contrast to this, as shown above, in an acidic solution almost no edge shift was found. This is in agreement with a remarkably higher solubility of $\mathrm{Fe}(2+)$ species in acidic solutions as compared to $\mathrm{Fe}(3+)(18)$. However, the behavior in the halide solutions suggests that compared with protons, a less specific effect of halides on $\mathrm{Fe}(2+)$ than on $\mathrm{Fe}(3+9$ takes place. For $\mathrm{Fe}(2+)$ only little data is found concerning the halide complex formation; however the values reported in ref. (17) are in a similar range for $\mathrm{Fe}(2+)$ and $\mathrm{Fe}(3+)$. Hence, the increased dissolution rate of the oxide films by halides is due to complexation of both $\mathrm{Fe}(2+)$ and $\mathrm{Fe}(3+)$.

In Fig. 11, the influence of an addition of $\mathrm{NaCl}$ and $\mathrm{NaF}$ in the borate buffer on the dissolution rate during reduction is shown as function of the $\mathrm{Cr}_{2} \mathrm{O}_{3}$ content of the oxide film. The dissolution rates were determined from the drop of the XANES edge height during galvanostatic reduction experiments. For pure $\mathrm{Fe}_{2} \mathrm{O}_{3}$, no acceleration of reductive dissolution is observed. However, it has been shown elsewhere that chemical dissolution of Fe oxide at potentials above the reductive dissolution region is enhanced in presence of $\mathrm{Cl}^{-}$in acidic solutions (5). Also addition of $\mathrm{NaF}$ in acidic solutions very strongly accelerates dissolution of $\mathrm{Fe}_{2} \mathrm{O}_{3}$. Hence, it is not a priori clear, why no effect of halide ions on the reductive dissolution rate could be found. However, in the case of mixed oxide films (which show a significantly lower dissolution rate in borate buffer as compared with pure $\mathrm{Fe}_{2} \mathrm{O}_{3}$ ) presence of $\mathrm{Cl}^{-}$and even stronger $\mathrm{F}^{-}$accelerates dissolution. In the case of pure $\mathrm{Cr}$ oxide, dissolution was found to be independent of the anion present in the solution $\left(\mathrm{F}-/ \mathrm{Cl}-/ \mathrm{SO}_{4}{ }^{2-}\right)$. Thus the increase in the dissolution rate by halides observed for mixed oxide films must be due to their specific action on the Fe oxide component of the films.

Since halide / metal ion complex formation can be a major factor determining the dissolution rate of metal oxides, one has to consider the halide complex formation of $\mathrm{Cr}(3+)$, as well. According to ref. (17), a strong tendency for $\mathrm{F}^{-} / \mathrm{Cr}^{3+}$ complex formation has been reported (for $\mathrm{Cr}^{3+}$ cations in solution). But as it has been pointed out by Strehblow (19), dissolution behavior of $\mathrm{Cr}$ oxide and complexing properties of $\mathrm{Cr}$ can be considered as a special case due to thermodynamic and kinetic reasons, which make $\mathrm{Cr}$ oxide films stable even in aggressive halide-containing solutions.

The specific action of halide anions on the Fe component of the oxide films is illustrated in Fig. 12. Here both the $\mathrm{Fe}$ and $\mathrm{Cr}$ XANES edge are shown during galvanostatic reduction of a $20 \% \mathrm{Cr}_{2} \mathrm{O}_{3}-80 \% \mathrm{Fe}_{2} \mathrm{O}_{3}$ oxide film in borate buffer $+1 \mathrm{M} \mathrm{NaF}$. For $\mathrm{Fe}$ 
oxide, slight dissolution is observed in the beginning of the experiment In the $\mathrm{Cr}$ spectrum, no dissolution can be seen. This suggests that fluoride is selectively dissolving Fe oxide out of the mixed oxide. Hence, it is possible that the surface layer becomes enriched with insoluble $\mathrm{Cr}$ oxide, and dissolution stop is obtained.

\section{CONCLUSIONS}

The stability of artificial $\mathrm{Fe} / \mathrm{Cr}$ passive films (sputter-deposited $\mathrm{Fe} / \mathrm{Cr}$ oxide films on inert substrates) is strongly influenced by the solution chemistry.

- low $\mathrm{pH}$ and presence of halides ( $\mathrm{Cl}^{-}$and $\mathrm{F}^{-}$) accelerate dissolution due to the solubility of $\mathrm{Fe}$ oxides in these solutions

- F- leads to a selective dissolution of Fe oxide out of the mixed oxide

- $\mathrm{Cr}_{2} \mathrm{O}_{3}$ is not attacked by fluoride; hence if the oxide film contains a sufficient amount of

$\mathrm{Cr}$ oxide, dissolution stop is obtained by surface enrichment of $\mathrm{Cr}$ oxide

Apart from the solution chemistry, the composition of the oxide film is crucial for its stability.

- an increasing $\mathrm{Cr}_{2} \mathrm{O}_{3}$ content increases the resistance against reductive dissolution

- an increasing $\mathrm{Cr}_{2} \mathrm{O}_{3}$ increases the resistance in aggressive solutions (low $\mathrm{pH}$, halides)

- an increasing $\mathrm{Cr}_{2} \mathrm{O}_{3}$ decreases the resistance against oxidative dissolution

- an increasing $\mathrm{Fe}(2+)$ content in the oxide film strongly accelerates dissolution in acidic solutions

\section{ACKNOWLEDGMENTS}

The authors would like to thank Mike Sansone (Beamline X10C) and Lars Furenlid (Beamline X19A) for help at the beamlines. This work was performed in part under the auspices of the U.S. Department of Energy, Division of Materials Sciences, Office of Basic Energy Science under Contract No. DE-AC02-76CH00016. Measurements were made at the National Synchrotron Light Source, Brookhaven National Laboratory, which is supported by the U.S. Department of Energy, Division of Materials Sciences and Division of Chemical Sciences.

\section{REFERENCES}

1 K. Sugimoto, M. Seto, S. Tanaka, and N. Hara, J. Electrochem. Soc., 140, 1586 (1993).

2 S. Tanaka, N. Hara, and K. Sugimoto, Materials Science \& Engineering, A198, 63 (1995).

3 P. Schmuki, S. Virtanen, H. S. Isaacs, A. J. Davenport, H. Böhni, and T. Stenberg, in Surface Oxide Films, J. A. Bardwell, Editor. Proc.-Vol. 96-18, p. 234, The Electrochemical Society, Pennington, NJ, (1996).

4 P. Schmuki, S. Virtanen, A. J. Davenport, and C. M. Vitus, J. Electrochem. Soc., 143, 574 (1996). 
5 S. Virtanen, P. Schmuki, A. J. Davenport, and C. M. Vitus, J. Electrochem. Soc., 144, 198 (1997).

6 P. Schmuki, S. Virtanen, A. J. Davenport, and C. M. Vitus, J. Electrochem. Soc., 143, 3997 (1996).

7 P. Vuoristo, $P h D$ Thesis, Tampere University of Technology, Tampere, Finland, (1991).

8 T. Stenberg, J. Keränen, P. Vuoristo, and T. Mäntylä, Abstract for EUROMAT 97, (1996).

9 T. Stenberg, P. Vuoristo, J. Keränen, T. Mäntylä, M. Büchler, S. Virtanen, P. Schmuki, and H. Böhni, Thin Solid Films, (in press).

10 A. J. Davenport and M. Sansone, J. Electrochem. Soc., 142, 725 (1995).

11 M. Kerkar, J. Robinson, and A. J. Forty, Faraday Discuss. Chem. Soc., 89, 31 (1990).

12 W. Khalil, S. Haupt, and H.-H. Strehblow, Werkstoffe und Korrosion, 36, 16 (1985).

13 K. E. Heusler and L. Fischer, Werkstoffe und Korrosion, 27, 551 (1976).

14 H.-H. Strehblow, B. Titze, and B. P. Löchel, Corros. Sci., 19, 1047 (1979).

15 B. Löchel and H.-H. Strehblow, Electrochimica Acta, 28, 565 (1983).

16 H. Böhni, in Corrosion Mechanisms, F. Mansfeld, Editor, Marcel Dekker, Inc., New York \& Basel, (1987).

17 L. G. Sillen and A. E. Martell, Stability constants of metal-ion complexes, The Chemical Society, London, (1964).

18 M. A. Blesa, P. J. Morando, and A. E. Regazzoni, Chemical Dissolution of Metal Oxides, CRC Press, Boca Raton, FL, (1994).

19 H.-H. Strehblow, in Electrochem. Soc. Meeting Abstracts, San Antonio, TX, 96-2, The Electrochem. Soc., (1996). 


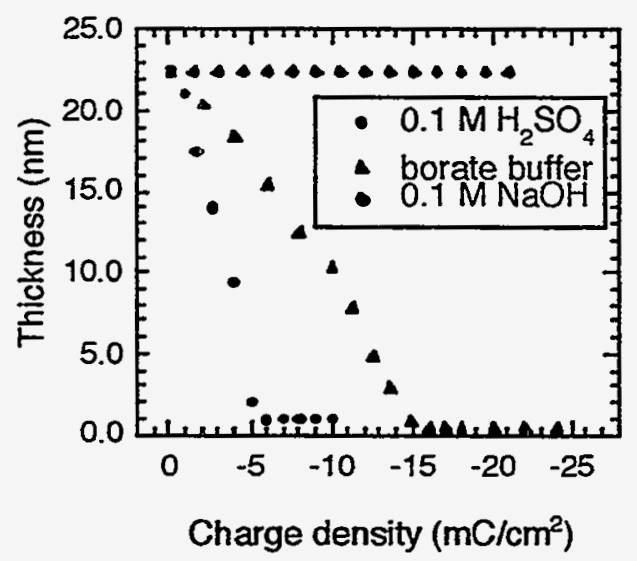

Fig. 1 Thickness of a sputter-deposited $\mathrm{Fe}_{2} \mathrm{O}_{3}$ film as a function of charge density during galvanostatic reduction in different solutions. Thickness determined from the edge height of the XANES spectra.

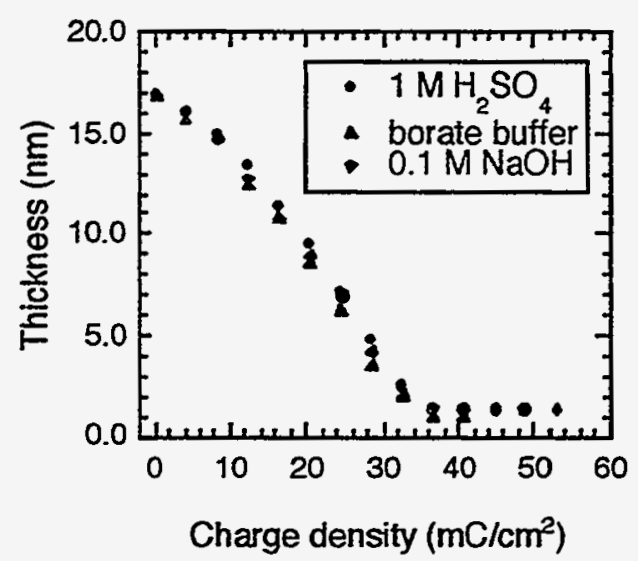

Fig. 2 Thickness of a sputter-deposited $\mathrm{Cr}_{2} \mathrm{O}_{3}$ film as a function of charge density during galvanostatic oxidation in different solutions. Thickness determined from the edge height of the XANES spectra.

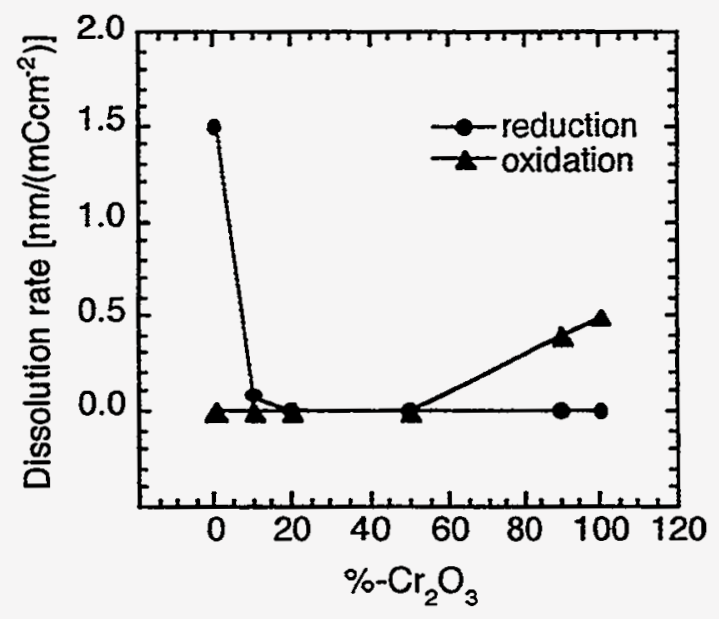

Fig. 3 Dissolution rate of sputter-deposited Fe/Cr oxide films as a function of the $\mathrm{Cr}_{2} \mathrm{O}_{3}$ content during galvanostatic reduction and oxidation in borate buffer, $\mathrm{pH} 8.4$.

Dissolution rates determined from the drop of the edge height of the XANES spectra during the experiments. 

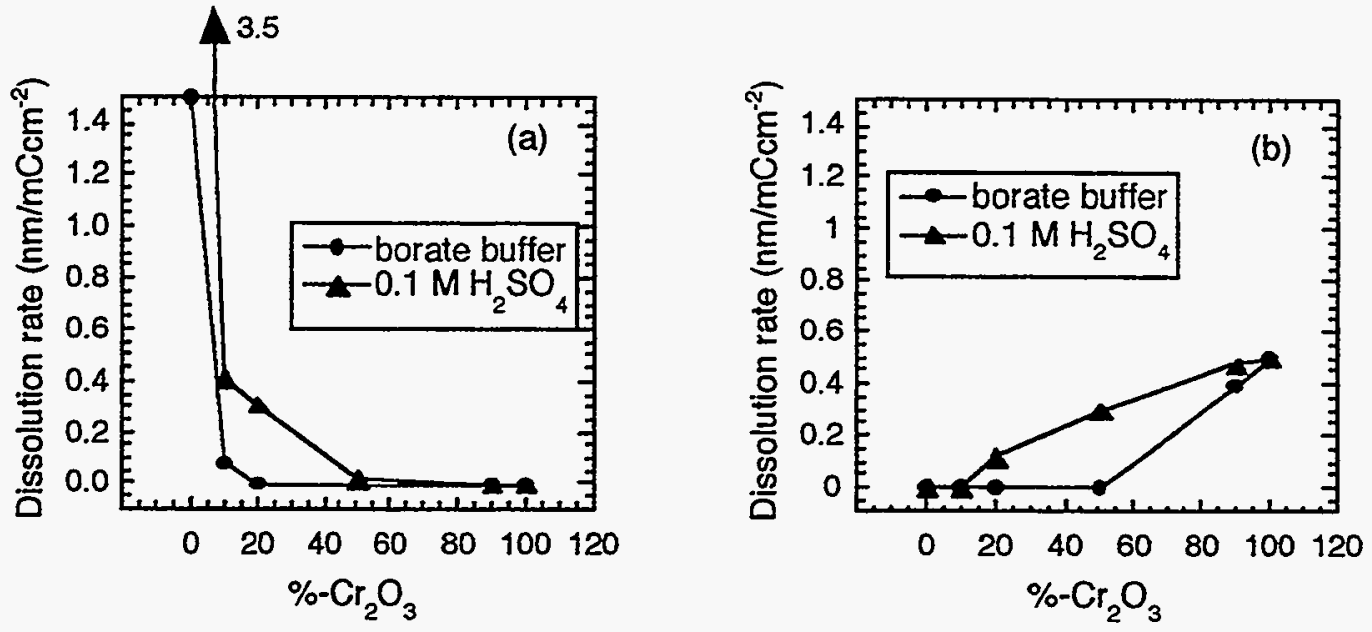

Fig. 4 Dissolution rate of sputter-deposited $\mathrm{Fe} / \mathrm{Cr}$ oxide films as a function of the $\mathrm{Cr}_{2} \mathrm{O}_{3}$ content in borate buffer, $\mathrm{pH} 8.4$ and in $0.1 \mathrm{M} \mathrm{H}_{2} \mathrm{SO}_{4}$

a) during galvanostatic reduction

b) during galvanostatic oxidation
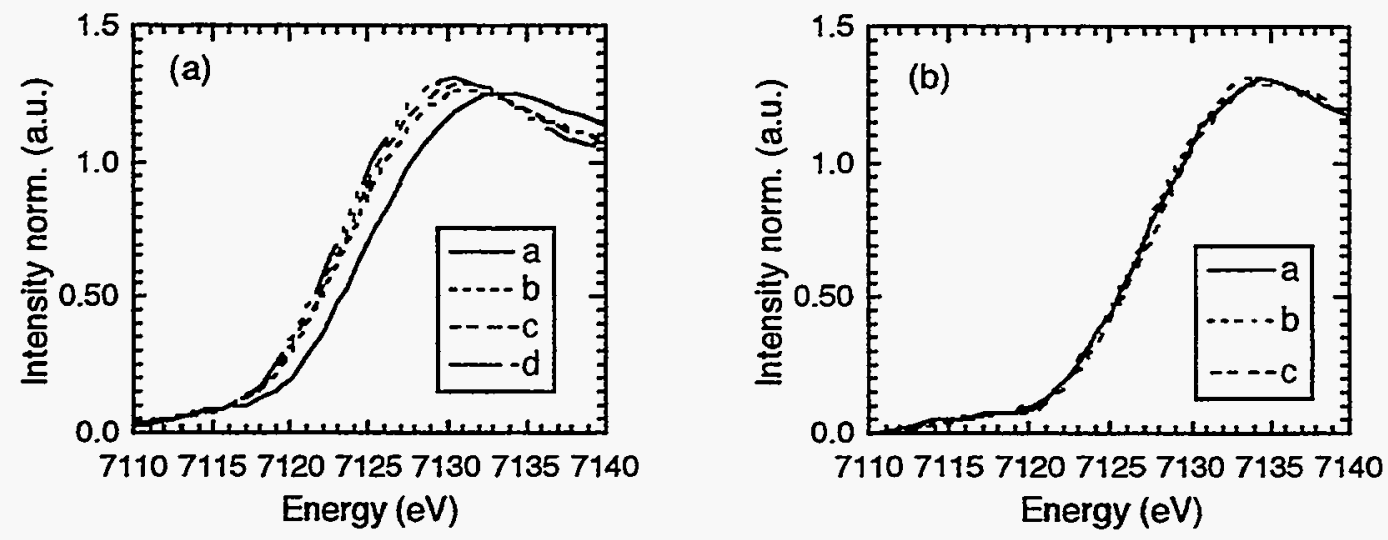

Fig. 5 Normalized XANES Fe edge during galvanostatic reduction $\left(-10 \mu \mathrm{A} / \mathrm{cm}^{2}\right)$ of a $10 \% \mathrm{Cr}_{2} \mathrm{O}_{3}-90 \% \mathrm{Fe}_{2} \mathrm{O}_{3}$ oxide film in

a) borate buffer

b) $0.1 \mathrm{M} \mathrm{H}_{2} \mathrm{SO}_{4}$

Spectra a...c, d are consecutive spectra during the reduction. 


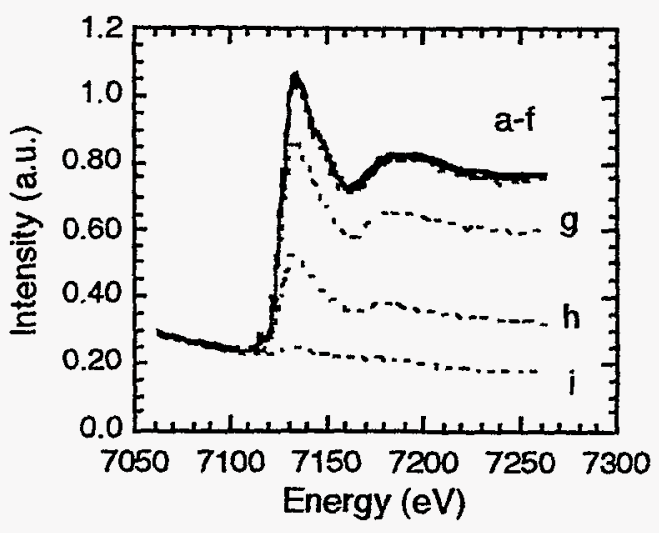

Fig. 6 XANES spectra (Fe edge) of a $20 \% \mathrm{Cr}_{2} \mathrm{O}_{3}-80 \% \mathrm{Fe}_{2} \mathrm{O}_{3}$ sample during anodic potential steps in $0.1 \mathrm{M} \mathrm{H}_{2} \mathrm{SO}_{4}$ a-f: $0 . .600 \mathrm{mV}(100 \mathrm{mV}$ steps $)$ g-i: Consecutive spectra at $+700 \mathrm{mV}$

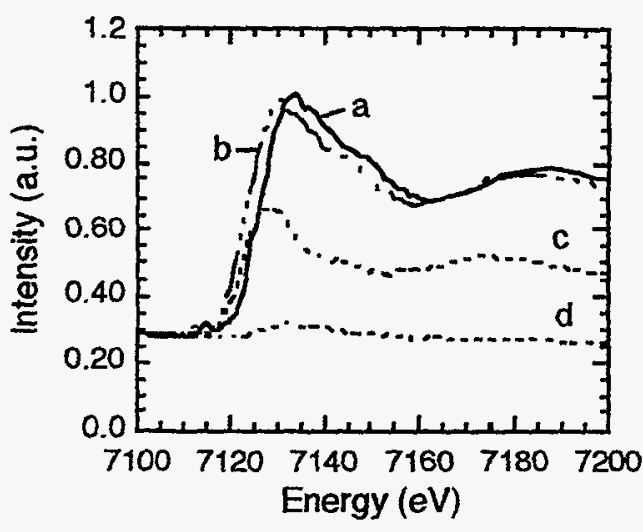

Fig. 7 XANES spectra (Fe edge) of a $20 \% \mathrm{Cr}_{2} \mathrm{O}_{3}-80 \% \mathrm{Fe}_{2} \mathrm{O}_{3}$ sample a: open-circuit potential in borate buffer

$\mathrm{b}$ : after galvanostatic reduction in borate buffer c, d: $0 \mathrm{mV}$ in $0.1 \mathrm{M} \mathrm{H}_{2} \mathrm{SO}_{4}$

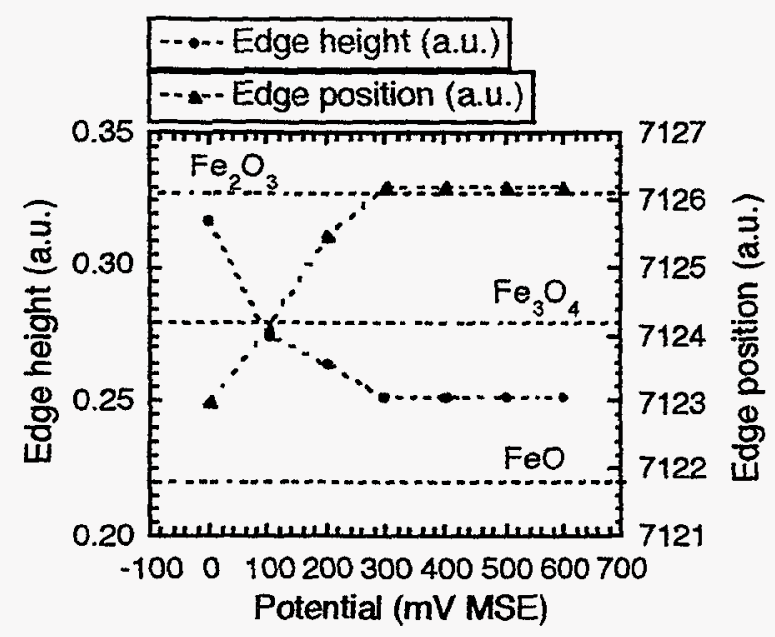

Fig. 8 Edge height and edge position of Fe XANES spectra as a function of potential for a $50 \% \mathrm{Cr}_{2} \mathrm{O}_{3}-50 \% \mathrm{Fe}_{2} \mathrm{O}_{3}$ sample during anodic potential steps in $0.1 \mathrm{M} \mathrm{H}_{2} \mathrm{SO}_{4}$ after galvanostatic reduction in borate buffer 

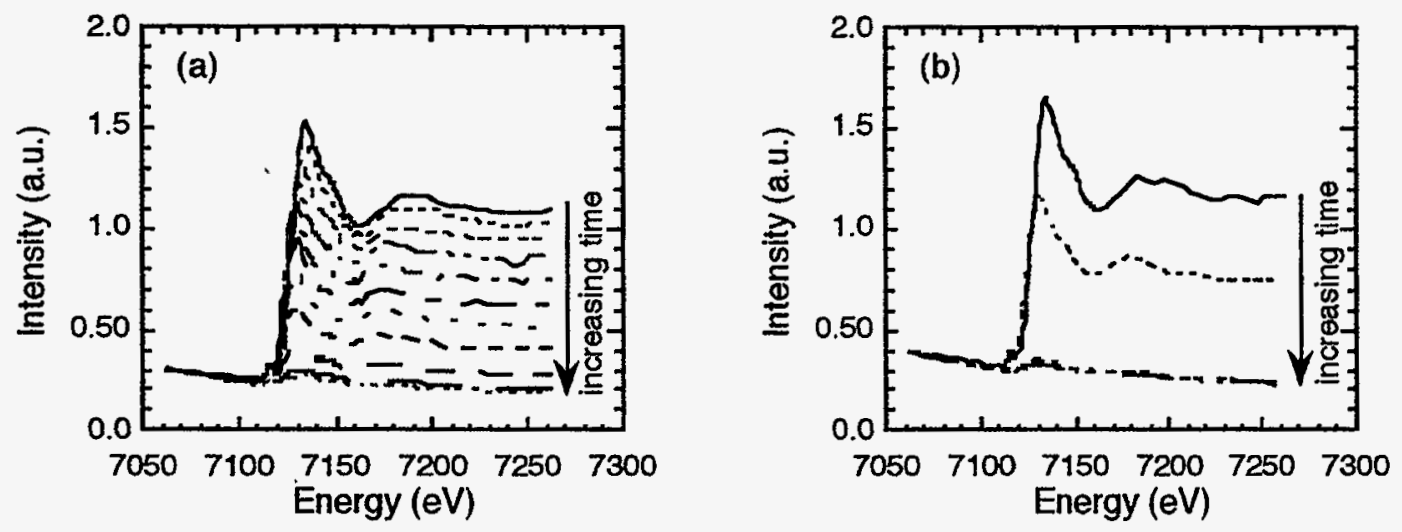

Fig. 9 Consecutive XANES spectra for the Fe edge of a $10 \% \mathrm{Cr}_{2} \mathrm{O}_{3}-90 \% \mathrm{Fe}_{2} \mathrm{O}_{3}$ sample during galvanostatic reduction $\left(-10 \mu \mathrm{A} / \mathrm{cm}^{2}\right)$

a) in borate buffer $+1 \mathrm{M} \mathrm{NaCl}$

b) in borate buffer $+1 \mathrm{M} \mathrm{NaF}$
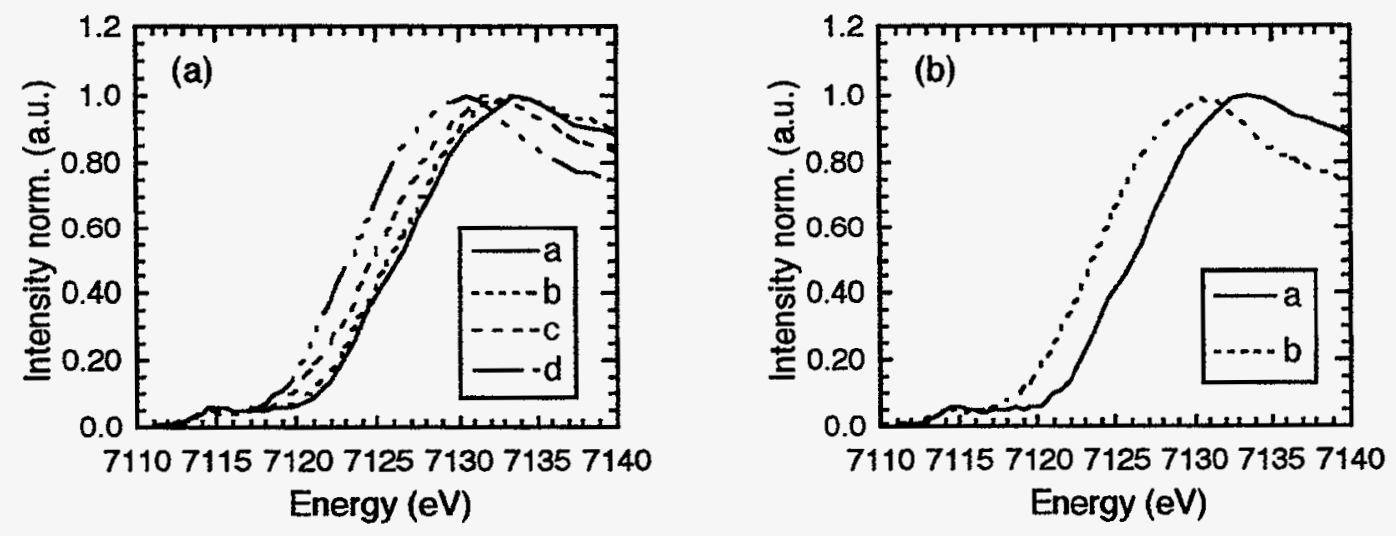

Fig. 10 Normalized XANES Fe edge of a $10 \% \mathrm{Cr}_{2} \mathrm{O}_{3}-90 \% \mathrm{Fe}_{2} \mathrm{O}_{3}$ oxide film during galvanostatic reduction $\left(-10 \mu \mathrm{A} / \mathrm{cm}^{2}\right)$

a) in borate buffer $+1 \mathrm{M} \mathrm{NaCl}$

b) in borate buffer $+1 \mathrm{M} \mathrm{NaF}$ 

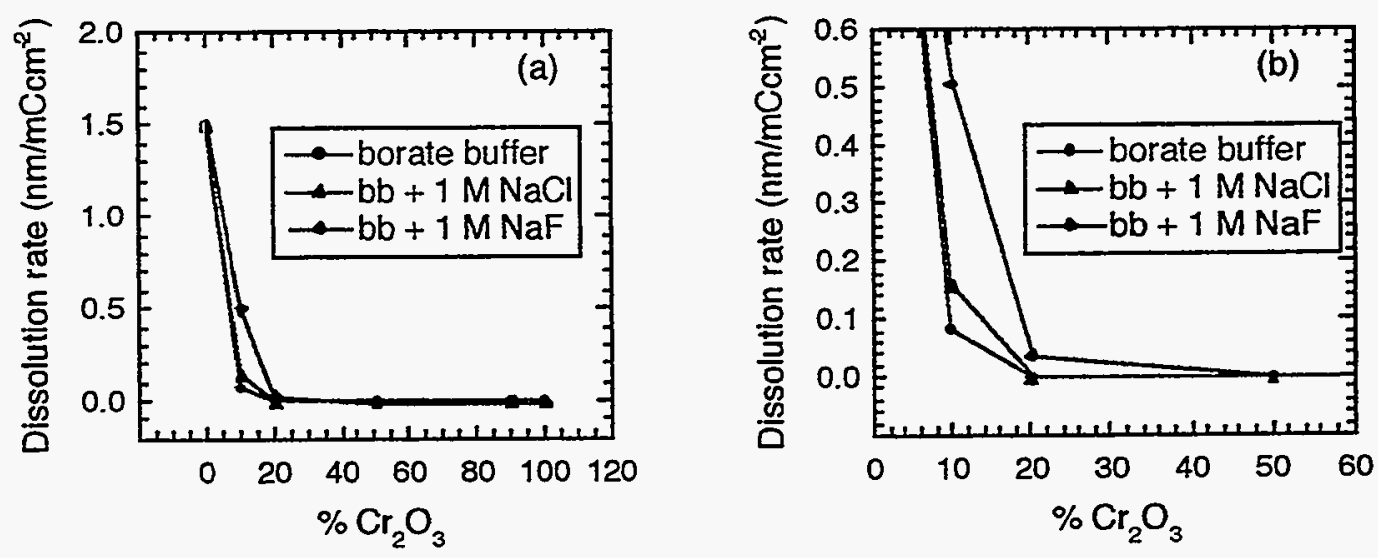

Fig. 11 Dissolution rate (determined from XANES edge heights) during galvanostatic reduction of $\mathrm{Fe} / \mathrm{Cr}$ oxide films in borate buffer with additions of $\mathrm{NaCl}$ or $\mathrm{NaF}$.

a) full scale; b) expanded scale
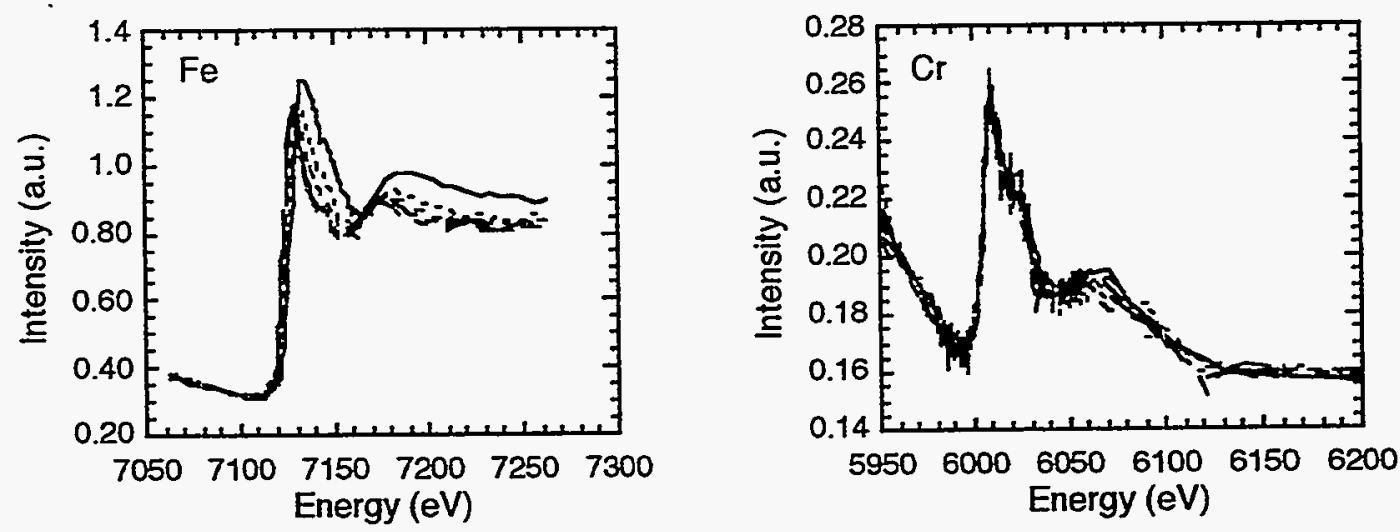

Fig. 12Fe and $\mathrm{Cr}$ XANES spectra during galvanostatic reduction of a $20 \% \mathrm{Cr}_{2} \mathrm{O}_{3}-80 \% \mathrm{Fe}_{2} \mathrm{O}_{3}$ oxide film in borate buffer $+1 \mathrm{M} \mathrm{NaF}$ 